\section{Géneros}

Multidisciplinary Journal of Gender: Studies

\section{Hipatia Press \\ www.hipatiapress.com}

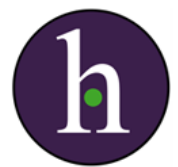

Instructions for authors, subscriptions and further details:

$\underline{\text { http://generos.hipatiapress.com }}$

\title{
Undermining Dichotomies: Women and the Peace Process in Afghanistan
}

Marissa Quie ${ }^{1}$

1) Department of Sociology, University of Cambridge, Cambridge, United Kingdom.

Date of publication: February $25^{\text {th }}, 2017$

Edition period: February - June 2017

To cite this article: Quie, M. (2017). Undermining Dichotomies. Women and the Peace Process in Afghanistan. Multidisciplinary Journal of Gender Studies, 6(1), 1187-1207. doi: 10.17583/generos.2017.2254

To link this article: http://dx.doi.org/10.17583/generos.2017.2254

\section{PLEASE SCROLL DOWN FOR ARTICLE}

The terms and conditions of use are related to the Open Journal System and

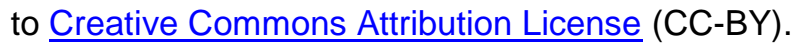




\section{Undermining Dichotomies: Women and the Peace Process in Afghanistan}

Marissa Quie

University of Cambridge

\section{Abstract}

This paper interrogates the equation of women and peace through the prism of the Afghanistan Peace and Reintegration Program (APRP). The Program was designed to create the conditions for inclusion of the insurgency within the democratic system and provide a roadmap for peace. It builds on a central justification of the war: the liberation of Afghan women. It requires gender mainstreaming in accordance with United Nations Security Council Resolution (UNSCR) 1325 and subsequent Resolutions, to include women in all stages of the process. The APRP underscores tensions between international and local standards that claim to ensure women's interests are protected in peacebuilding. The effort to impose gender mainstreaming is emblematic: yielding partial gains for women who have internalized international perspectives on their rights, but excluding those who have not.

Keywords: Afghanistan, APRP, peace, exclusion, marginalization, women 


\section{Dicotomías Debilitadoras: Mujeres y Proceso de Paz en Afganistán}

Marissa Quie

University of Cambridge

\section{Resumen}

Este documento interroga la ecuación de la mujer y la paz a través del prisma del Programa de Paz y Reintegración de Afganistán (APRP). El Programa fue diseñado para crear las condiciones para la inclusión de la insurgencia dentro del sistema democrático y proporcionar una hoja de ruta para la paz. Se basa en una justificación central de la guerra: la liberación de las mujeres afganas. Ello requiere la incorporación de la perspectiva de género de conformidad con la resolución 1325 del Consejo de Seguridad de las Naciones Unidas y las Resoluciones posteriores, para incluir a las mujeres en todas las etapas del proceso. La APRP subraya las tensiones entre los estándares internacionales y locales que pretenden asegurar que los intereses de las mujeres estén protegidos en la consolidación de la paz. El esfuerzo para imponer la incorporación de la perspectiva de género es emblemático: se obtienen beneficios parciales para las mujeres que han interiorizado las perspectivas internacionales sobre sus derechos, pero excluyendo a quienes no lo han hecho.

Palabras clave: Afghanistan, APRP, paz, exclusión, marginación, mujer 
I suffer not the work of any worker, male or female, to be lost (The Family of Imran, The Qur'an).

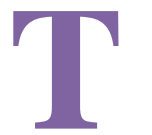

he Afghanistan Peace and Reintegration Program (APRP) was launched in 2010 to create the conditions for coexistence and dialogue with the Taliban. The Program builds on a central justification for the war: the liberation of Afghan women (Abu-Lughod, 2002).

Gender mainstreaming is a principal tenet of the process, stemming from ideas codified within United Nations Security Resolution (UNSCR) 1325 and subsequent Resolutions (1820, 1888, 1889, 1960, 2106, and 2122). These are targeted not only at the disproportionate impact of war on women, but also at the pivotal role women should and do play in conflict resolution and the realization of durable peace. The APRP underscores inevitable tensions between international and local standards that claim to ensure women's interests are protected in peacebuilding. The effort to impose gender mainstreaming is emblematic of this.

I argue that this effort has yielded partial gains for women who have internalized international perspectives on their rights, but excluded those who have not. Moreover, even those women who have benefited suffer from the paradox of being both seen and unseen. As standard bearers of what is often perceived as cultural imperialism, they are vulnerable to violent counterattack in the context of ongoing war.

The Women Peace and Security (WPS) agenda underpinning gender mainstreaming assumes symmetry in the positions of men and women: but fails to address the complex ways in which gender is perceived by power relations within particular societies. Considering men and women as though they confront similar obstacles reifies disparities between them. Formal numerical inclusion in the APRP, as in other political processes, has not and cannot ensure changed practices.

I want to interrogate what counts as participation. For women in rural communities, productive participation leads to a range of practical manifestations of agency in family and community life. It is a priority for women to realize peace and security, but different cultural requirements are needed for this. Participation has to be inclusive of difference. 
The discourse of the War on Terror concerning the "liberation of Afghan women" (Abu-Lughod, 2002) continues to contaminate the peace process and international attempts to ensure women's participation. There is a sharp focus on the gender apartheid of the Taliban, accompanied by neglect of more subtle forms of marginalization. While women's and human rights groups involved in the APRP have largely internalized Western narratives on gender equality, a range of alternative views exist. These groups cannot speak for all Afghan women. Marginalization or exclusion of women from post-conflict decisionmaking processes means that the specific issues surrounding women's vulnerability may not be adequately addressed, or even at all.

The Taliban were neither the architects of women's oppression in Afghanistan nor the only current source of their disempowerment. Feminist scholarship pays inadequate attention to the role of warlords in contemporary Afghan democracy and their ties with some women at the forefront of the peace process (Wordsworth, 2007, p. 3). These connections are overlaid by differences in ethnicity, tribe and class. Within the neat friend/enemy dichotomy, conflict-induced differences between women are overlooked.

Both the Afghan government and Taliban interlocutors to the peace process understand the value of the term 'gender' as a tool for legitimization and mechanism for external funding, which the APRP is entirely dependent upon (Quie, 2012). This at least ties the Program to rhetoric on gender mainstreaming. In reality, however, key protagonists are resistant to the very word 'gender.'

Afghans say that stories are the data of the soul. One that aptly captures the tensions surrounding the use of 'gender' in the APRP concerns a male colleague responsible for outreach to local women in Kandahar. A man fulfilled this role because of the intensity of conflict in the province. Women could not obtain security approval for the job. I asked him about his interactions with women and views on gender mainstreaming. He replied:

Gender is not a word I use in Kandahar. It is still confusing for us. People in local villages think it is a 'foreign invention.' They don't know what it means and neither do I. Instead, I translate it into our own language (Interview with Abdul Baser Miyakhil, 2010).

This anecdote highlights key problems I set out in this paper. Universal notions of freedom and participation encoded in the WPS agenda are not easily translatable in the Afghan context. The attempt to do this instead results in a loss of culturally relevant nuances surrounding local understandings of 


\section{Quie - Women and the Peace Process in Afghanistan}

these ideas. Potentially, this generates what, in the context of natural disasters, Harvey (2016) has termed as "secondary violences."

What happens when women's participation is mandated without a correlative effort to understand its complexities in an Afghan context? Why is there such a wide gap between the rhetoric and the realities of participation? Is all participation recognized, or do pre-conceived notions exclude those who fall outside these understandings? What is the significance of these exclusions? How does the dichotomization of gender and its link with peace and security undermine the potential for peace?

Although the media and international community depict the conflict through the bounded image of a friend/enemy distinction, it is far more complex. The former Gender Advisor to the APRP, Quhramaana Kakar, noted:

Now threats are everywhere. There is no clear enemy. At times, Taliban representatives to the peace process are more open to recognizing women than corrupt government officials. Even close family members can pose a threat to women's participation in conflict resolution and more fundamentally, to their safety (Interview, 2014).

Baryali Helali, a communications advisor to the peace process, said, "the peace program calls the Taliban 'brothers,' but we don't see them as an enemy to be destroyed (Interview, 2011).

The Taliban have never articulated a comprehensive political vision. On paper, they demand an Islamic Emirate based on a strict interpretation of Sharia - but this eschews gender equality as understood within the WPS framework. Further challenges are entailed by the tensions between Afghanistan's formal endorsement of UNSCR 1325 and subsequent Resolutions on the one hand and the primacy of Islamic law on the other.

Article 7 of the Constitution affirms that "Afghanistan shall observe the UN Charter, inter-state agreements and international treaties it has joined." Yet Article 3 states that "no law can be contrary to the beliefs and provisions of the sacred religion of Islam." This is reinforced by Article 130, which affirms that Hanafi law takes precedence when no provisions in the Constitution or other laws relate to specific cases (Afghanistan Online).

The tension between recognition of international human rights norms and Islam creates broad latitude for interpretation. A senior Taliban representative to the APRP, Mullah Hotak, acknowledged that the treatment of women under 
their regime had been "costly," and that they should be afforded "equal but different" recognition (Interview, 2010).

The notion of 'difference' is at odds with the WPS agenda; yet this term was prevalent among diverse actors in the peace process. The Deputy Minister to the APRP, Aziz Ahmadzai, cautioned against "one size fits all" attempts to empower women and involve them in conflict resolution: "Without cultural sensitivity and appreciation of difference, women will suffer more" (Interview, 2010). Women in conservative rural areas targeted by the APRP further highlighted the problem of 'difference': placing more emphasis upon influence within their families and communities than on individual rights.

The stress on 'difference' indicates that the WPS agenda does not seem to 'translate' well across differing cultural contexts. The prime focus of this research is therefore to explore the impact of gender mainstreaming on the Afghan peace process. This is critical in identifying obstacles to the implementation of UNSCR 1325 and subsequent Resolutions, and understanding how women's participation may be recognized and enhanced. It is a priority for women to realize peace and security; but different cultural requirements are required for this to be achieved.

UNSCR 1325 (2000) calls on member states to ensure the equal participation and full involvement of women in all efforts in peace and security promotion; and urges actors to incorporate a gender perspective. Subsequent Resolutions call for the further strengthening of women's participation in peace processes and the development of indicators to measure progress. Yet the Afghan peace process raises critical questions about what counts as participation, how it is manifested and ways in which it might be nurtured and developed.

Sixteen years after UNSCR 1325 was unanimously adopted, the conspicuous absence of women from peace negotiations underscores a disturbing gap between rhetoric and reality. A review of the APRP reveals that women have had little impact on the design or implementation of the process. In cases where women have been included, this has largely been an exercise of form over substance. Numerical inclusion cannot be equated with the notion of participation specified by the WPS agenda.

Within the family-centered and close knit rural communities of Afghanistan, women are conceptualized as the bearers of the family honour (haqq). Gender codes place the duty of protection on men. Women prove 


\section{Quie - Women and the Peace Process in Afghanistan}

themselves worthy of protection through adherence to strict moral norms, capacity for reproduction and roles as cares within the family. Transgression of gender codes routinely results in violence, including honor killings (Amnesty International, 2015).

Gender mainstreaming as practiced by the APRP brackets out masculinities; but this failure to address gender in a holistic way undermines the potential for attitudinal change. There are multiple forms of masculinity within Afghan communities, expressing both hierarchy and exclusion. Moreover, there is clearly a 'hegemonic' form of masculinity that ties in with patriarchy.

That said, men involved in the APRP often demonstrated a degree of ambivalence around masculinities. A Ministry official observed, "It is a problem that we don't allow our women to be educated. They are our servants but we are their servants" (Interview, 2010). The word 'gender' and the WPS agenda itself have come to be associated almost entirely with women. Yet men and boys are the gatekeepers of gender equality.

According to the sociologist, Raewyn Connell, "men predominate across the spectrum of violence" (Breines, Connell, \& Eide, 2000). She believes a strategy for peace must concern itself with this fact, the reasons for it, and its implications for violence. Masculinity is located within a structure of gender relations. Schwalbe (1992) argues that patriarchy - that is to say, the structure of gendered power - limits men's capacities to take the position of the 'other' and engage in an ethic of care.

This argument is highly relevant to the question of peace. Yet masculinity is not merely a static 'place' in a map of gender relations. Rather, it is an active social construction, a pattern of social conduct, which responds to the situations in which individuals find themselves.

The rhetoric of the War on Terror co-opted Western feminists: who viewed the intervention as a means of rescuing oppressed Afghan women. The pervasive epigram of the burqa depicts these women as shrouded by religion and patriarchy. Western media portrayals continue to recycle these images, obscuring cultural meanings and possibilities for agency. The positing of women's agency as co-substantial to relations of domination and the concomitant normalization of freedom/autonomy as an ideal is woven into the WPS agenda. 
Theorists such as Abu-Lughod (2002) offer a different reading. She refers to Papenak's description of the burqa as "portable seclusion." This presents adherence to cultural tradition (specifically, the veil) as signifying "belonging to a particular community and participating in a moral way of life in which families are paramount in the organization of communities and the home is associated with the sanctity of women" (Abu-Lughod, 2001).

Through their metamorphosis as subjects with duties and obligations into individuals with rights and freedoms, women participating in the APRP are not merely "free to choose" but obliged to be free, "to understand and enact their lives in terms of choice" (Rose, 1999, p. 87). Yet not only is this at variance with traditional conceptions of freedom within Afghan society; it is incompatible with what those women who have internalized Western discourses of rights want from the peace process. Within the critical reintegration phase of the APRP, these women opted for community-based recovery, repudiating ideas of individual rights and freedoms.

\section{Methodology}

This research aims to provide a context-based, qualitative analysis of the APRP through participatory observation and analysis of secondary sources. It derives from my role as a Consultant to the APRP between 2010 and 2016, focusing on the Ministry of Rural Rehabilitation and Development, the Ministry of Agriculture and the Ministry of Labor. My remit involved consultation with Afghan women, human rights groups, and other representatives of civil society. I also participated in consultations with the Taliban, alongside JS and International Security Assistance Force (ISAF) staff. As part of the implementation phase, I structured specialized development programs for former insurgents and ideas for de-radicalization centers.

Given the above, there is a risk of bias; but this is outweighed by access to highly sensitive sources: including reports on the emerging reintegration and reconciliation strategy, semi-structured interviews with Afghan and international stakeholders, primary documents connected with the APRP, media reports, recorded and unofficial conversations held in Kabul between April and November 2010, and correspondence or Skype interviews with Afghan leaders, carried out between November 2010 and July 2016. 


\section{Quie - Women and the Peace Process in Afghanistan}

Translators were used for interviews in Pashtu. This implies multiple possibilities for distortion; but every effort was made to verify the research presented. A context of extreme violence shaped the kinds of questions asked and information provided, mostly owing to the potential for the security of those interviewed to be compromised.

\section{Gendered Dichotomies}

Binary distinctions solidify the definition of women during the application of gender mainstreaming in the APRP. The central dichotomy of the WPS agenda is that of opposition between men and women in terms of war and peace. Harris and King (1989) argue that this distinction between aggressive, war-making men and nurturing, peaceful women is deeply problematic. Such myths tend to reinforce militarism, devalue women and de-legitimize multiple forms of agency deployed in the quest for peace.

The association between fighting and masculinity is clearly evident in the APRP. In June 2010, President Hamid Karzai convened The National Consultative Peace Jirga (NCPJ), in order to confer the Program with the seal of democratic legitimacy. From the outset, female representatives to the NCPJ expressed their sense of exclusion, referring to their "unique experience of war and deprivation and their emergence as survivors" (APRP, 2010).

Women's representatives drafted detailed proposals for applying United Nations Security Council Resolutions (UNSCR) 1325, 1820, 1888, 1889, 1960, 2106 and 2122; the 2004 Constitution (Afghanistan Online); and elements of the Afghanistan New Beginnings Program (UN Partnership for Peace), to include women in all stages of the process. They asked that a National Action Plan on Women, Peace and Security (Ministry of Foreign Affairs, 2015) be integrated as a core element of future national security policy. They sought a concrete process to encourage religious leaders to speak out on women's rights in Islam. They called for the APRP to promote access to education, health, justice, and other basic services; and improve awareness of women's rights through effective implementation (Nemat, 2011, pp. 32-9).

They also called for greater civic education, in order to raise awareness of women's rights at community level and improve support for female leadership in the peace process. They wanted independent monitoring of all government actions, particularly the peace process, as international forces withdrew. A 
majority supported gender mainstreaming throughout the APRP. Finally, they demanded a transparent system of monitoring/evaluation and a voice in the APRP Trust Fund, to ensure that financial incentives for reintegration were used to support women's empowerment and development and the protection of their rights (Interviews with members of the Afghanistan Independent Human Rights Commission (AIHRC) and the Afghan Women's Network, 2010-2014).

International donors to the Program insisted on recorded consultations with women and human rights groups - yet the ministry charged with design and implementation, the Joint Secretariat (JS), intentionally avoided this. The recommendations drawn up by women were not disseminated. Instead, both international and Afghan actors prioritized rapid implementation over a consultative design strategy. An international consultant noted, "Time is a luxury we don't have" (JS Meeting, June 2010).

Consequently, international actors only monitored the number of meetings that the JS held with women, rather than their qualitative impact. In correspondence, donors referred to the need for "cultural sensitivity" (Meetings with JS donors, June 2010). An international actor verbally advised of the need for "avoiding confrontation and any trace of cultural imperialism" (Ibid). JS officials, meanwhile, were savvy in their understanding of gender mainstreaming. They fulfilled the 'formal' requirement for women to participate in the process - but did not allow them a genuine voice.

This small snapshot illustrates the double marginalization which women activists experienced. Already excluded from the post-2001 political compact, they now found themselves marginalized by a charade of participation. The hidden rationale of JS officials is that "women don't participate in war and therefore have no real role in the pursuit of peace" (Interviews with JS officials, 2010-12), which echoes fundamental elements of international positions too.

The friend/enemy dichotomy has also resulted in further divisions which undermine the recognition of women's participation. In designing the process, ISAF pressed for 'de-radicalization': emphasizing the need for civic education to reintegrate former combatants. This was consistent with their understanding of the Taliban as an 'enemy.'

Women's and civil rights representatives concurred, believing it to be critical in transforming the consciousness of former fighters and their 


\section{Quie - Women and the Peace Process in Afghanistan}

communities, in order to cultivate a form of peace that reflected these rights (Interviews with female NCPJ representatives, 2010). Orzala Ashraf Nemat, a women's rights activist, asked, "What is the point of asking reintegrating combatants to accept the Constitution when they don't know what's in it?" (Interview, 2014) Nemat's question highlights the attention paid to rhetoric over practice.

Three ministries, including the Ministry of Hajj and Religious Affairs, were tasked with developing civic and vocational education. Yet leading JS officials rejected de-radicalization and were indifferent to civic education. They explained this was a response to what they considered an attack on "Afghan ownership." In reality, it may have owed to regular threats of violence from the Taliban.

The question of de-radicalization was particularly sensitive because it touched upon 'moderate' interpretations of Islam: which women and civil rights groups demanded as a vital component of the process. Senior JS officials argued that anything related to religion was off-limits for foreign actors, employing the rationale of "cultural sensitivity."

The eventual compromise was a much-diluted version of civic education, devised by ministries that demonstrated little enthusiasm for the APRP. Consequently, some ex-combatants undergo a weak type of de-radicalization, but most do not. This increases risks of recidivism and draws upon an exclusionary vision of peace and ownership. Conservative government actors were able to shrewdly exploit the idea of cultural imperialism. In the absence of a shared set of cultural meanings that facilitate intelligibility, women's voices were silenced.

Unlike South Africa, there are no Truth and Reconciliation Commissions in the Afghan peace process. Female representatives to the NCPJ asked for accountability for gender-based violence and other violations of women's rights and an end to impunity, particularly for sexual violence in war. They insisted on women's participation in transitional justice processes and the management of reparations. This demand continues to receive the backing of the Afghanistan Independent Human Rights Commission.

However, both the government and international actors focused merely on direct violence in war. 'Justice' is ostensibly achieved through what the ISAF Force Reintegration Cell (FRIC) refers to as "organic reconciliation" (Interview with Ileana Baca, 2011) within communities. This has been highly 
cost effective for international donors; but amounts to a capitulation to conservative Afghan factions, further constricting the space for genuine coexistence.

Fears that women's rights are being traded in exchange for reintegration and reconciliation with the Taliban were further underscored by the National Unity Government's recent pivot on the Constitution. President Ghani contends that a workable peace settlement will have to include a new Afghan Constitution, or institutional arrangements that allow the Taliban to become a legitimate part of the government (Haress, 2014).

This would provide for a loya jirga, in which representatives of the Taliban, the Afghan government, and civil society come together to amend the current Constitution or write an entirely new one. The price of peace for women who embrace the WPS agenda may therefore cost even more than war.

The pattern of form over substance is repeated in the representative dimension of the APRP. Both JS officials and Taliban interlocutors highlight what they perceive as the international community's "hypocrisy" in demanding 27\% female representation in Parliament and a significant position in the peace process by referring to the relatively low number of women in American and European political arenas. Some went further: warning of a "counterattack" on Afghan women involved.

Minister Stanekzai argued that measures to implement UNSCR 1325 under conditions of ongoing war and foreign occupation could be interpreted by Afghans as yet another form of colonial intervention. He referred to a "clash of civilizations" and the ways in which gender becomes a kind of "structuring principle" in contemporary debates between Western powers and Muslim countries. Against this background, opposition to mainstreaming women is tantamount to a reassertion of Afghan sovereignty (Interview, 2010).

The use of representation as a ruse for gender mainstreaming is also apparent within the showpiece leadership forum of the APRP. The HPC purportedly leads the peace and negotiation process. In reality, it does not play a central role in the effort to pursue negotiations with the Taliban. Under both President Ghani and his predecessor, Hamid Karzai, negotiations have largely taken place in secret.

Although nine of its 70 members are female, they cannot be said to provide a genuine voice for women. Female members of the Council whom I interviewed often spoke of being treated as "empty tokens" (Interviews, 2015- 
6). As in the Afghan Parliament, the presence of officials with known records of human rights abuses, war crimes and continuing links to illegal armed groups leads to a culture of fear and intimidation. This divides female members and renders them vulnerable to factional politics, ultimately silencing them.

Wordsworth (2007) maintains that contrary to the "romanticized portrayals in Western media," Afghan female politicians are divided "across ethnolinguistic, class, political and regional lines." Employing the concept of "multiple identities," she explains that women may have common interests, but other ties may be more significant. Women, like men, are also vulnerable to corruption.

In 2016, the Minister for Women's Affairs, Delbar Nazari, narrowly survived a vote of no confidence in Parliament. She was accused of corruption and professional ineffectiveness. The motion against Nazari illustrated the longstanding conflict between different female politicians for influence over the Ministry of Women's Affairs. War has fostered a culture of manipulation. The "patronage-based, zero-sum nature of Afghan politics contributes to a system where one person's gain is another's loss" (Ibid).

Moreover, secrecy and concealment are inherent in the operations of the APRP and silence women's voices. Although gender mainstreaming was mandated and a Gender Advisor appointed in 2010, the incorporation of women and recognition of their demands has been inconsistent. In July 2011, for example, 30 women from Hizb-i-Islami families approached Najira Zeweiri, a female representative on the HPC. Zeweiri put them in touch with the Gender Advisor, Kakar.

The women came to the JS at great risk, travelling from areas of intense conflict. Their message was clear: they were tired of war and the costs imposed on their families. They wanted their men to talk to the government: "We may not fight but we can influence our men." Yet they complained of "finding no space" for their voices within the process. They could not work and their children, particularly their daughters, could not pursue education. They wanted a genuine impact on the peace process and to set up a systematic program of talks (Interview, 2014).

Both the Head of the HPC, former President Rabanni (assassinated in 2011), and the Council were informed, but took no action. For them, participation in the conflict and its resolution was synonymous with combat 
and the decision to lay down arms. Kakar remarked that President Rabbani did not recognize the Hizb-i-Islami women's perceived influence within the family as action conducive to peace.

Interestingly, these women were themselves largely conservative and unlikely to have internalized Western ('foreign') narratives of women's rights. Recognition of their initiative may have legitimized calls by Afghan women's groups and international actors for a substantive role in the APRP. In an effort to placate Taliban participants (often rivals within the insurgency to Hizb-iIslami), however, the women's initiatives were sidelined. Their campaign was simply unacknowledged. This framing dichotomizes men as agents and women as passive pawns. Women were marginalized because they did not conform to constructed gender images (Elshatain, 1987, p. 4) of viable participation.

The same pattern can be observed in the trajectory of the NAPWA, a fundamental demand of female representatives to the NCPJ in 2010. More than five years later, it was finally launched by President Ghani - but appears to be yet another token designed in order to facilitate exclusion. No plan for implementation exists, no concrete set of responsibilities has been assigned to APRP institutions, and no timeline or budget has been proposed.

International donors are demanding remedies to these problems, and Ghani has assured women of full inclusion; but he will not "bother them until the right time" (Human Rights Watch, 2015). Women's activists interpret this as meaning that their participation is "an optional token" (Interviews with Wazima Frogh, 2015), rather than a critical component. Indeed, a 2014 report found that in 23 rounds of peace talks between the Afghan government and insurgency between 2005 and 2014, women were present on only two occasions (Oxfam, 2014).

The final phase of the APRP is perhaps most significant for the realization of women's participation, and is called "National Community Recovery." This is where reintegration of former combatants is achieved; but it disturbs fragile power balances. Women from Taliban families who may have suffered stigmatization often find themselves further punished. As the most powerless group within rural communities, they represent optimal targets.

Female fighters are virtually nonexistent in the Taliban. According to the JS, the number of female re-integree beneficiaries is so low, it could not be recorded. In deriving the equation between fighting and 'participation,' the 


\section{Quie - Women and the Peace Process in Afghanistan}

APRP does not recognize the indirect support women provided to the insurgency (Interview, 2010). Instead, women are conceptualized as inseparable from the family unit. This is highly problematic: although women do not carry weapons, they play critical roles in providing moral and logistical support to fighters. Reintegration/reconciliation is simply assumed through communities' acceptance of ex-combatants; but women enjoy no entitlements linked to their individual rights.

Their views are actually substantially at odds with the perspectives of international and Afghan government actors, but this is ignored. Gender mainstreaming only applies to women who champion "universal" principles of peace and security. This has serious implications for transnational feminist praxis, efforts to construct counter-hegemonic projects and transform dominant structures of power that give rise to war. It points to a real, pressing need to incorporate difference.

\section{Discussion}

Efforts to mainstream UNSCR 1325 into the APRP raise fundamental questions about how policy concepts are translated into practice. Evaluation of successful practice touches on interpretations of the meanings of equality, freedom and active agency. Much of the effort to 'translate' the WPS agenda is founded on un-nuanced dichotomies. A language of rights cannot fully capture the complications of lives actually lived. A vision of freedom as autonomy/freedom to choose is linked to participation: silencing action that falls outside these boundaries.

As Charlesworth and Chinkin (2002) note, the trouble with: "All types of gendered discourse is that it makes some courses of action impossible to contemplate... gendered discourses and thinking in dichotomies confines our perspective to simple either-or propositions."

Moreover, women's empowerment is perceived as a threat to Afghan culture and traditional values. Stanekzai advised that this framing could exacerbate violence: "Attitudinal change is critical." To remedy this, he suggested bringing concepts of male and female rights into public spaces through locally valued community practices (Interview, 2014).

Gendered discourse of 'rescue,' integral to legitimization of the War on Terror, also seeps into the APRP. The difficulty lies in the destination this 
implies. Postcolonial scholars emphasize that the idea of 'rescue' tends to be based on an equality norm modeled on Western liberalism (Abu-Lughod, 2002). In Foucauldian terms, liberal equality norms are naturalized within the WPS agenda. Alternative forms of freedom rooted within webs of legitimacy outside the borders of individual agency are overlooked or even excluded altogether.

The dichotomy of men as warriors and women as peacemakers obscures the extent to which women participants are affected by class-based, ethnic and tribal differences, all of which impact on capacities for agency. Afghanistan is a multi-ethnic society, where ethnic ties seem in most cases to trump gender-based solidarity.

Stanekzai drew attention to the paradox of "wanting to overcome invisibility while risking the dangers of being seen" (Interview, 2012). Wazima Frogh, co-founder of the Women Peace and Security Research Institute, reaffirmed the issue of risk: "We used to engage with lots of reintegrated Taliban but then many of the women were warned, some were attacked and injured and therefore we stopped." She has received multiple threats of violence because of her involvement in the APRP: "Telephone and face-to-face threats. People came to my house warning my father to stop his daughter from defaming and dishonoring him" (Interview, 2015).

The recent occupation of Kunduz substantiated the fear of violent consequences. In a systematic campaign, the Taliban ruthlessly pursued women in public roles, particularly activists for peace and democracy. Messages were left with their neighbors saying: "Return and you will be dead" (Interview, 2015).

This has been particularly terrifying for women because of Kunduz' violent past, including at least two cases of stoning (Nordland, 2010). It has taken years for women to feel secure enough to embrace public roles; now, they are targeted again. Omnipresent fear means that few will feel able to defend their positions in the peace process as it moves forward.

Important Afghan power asymmetries have also been concealed. The National Unity Government contains powerful warlords: including Abdul Rashid Dostum, the Vice-President. A number of women in positions of power have close ties with warlords. Ramazan Bashardost, a former candidate for the presidency, notes that much of the HPC "has more experience of war than of peace;" and that it is difficult to promote the WPS agenda through 
open debate when significant actors have access to substantial militias and do not hesitate to abuse their power (Interview, 2016).

Similarly, Azarabaijani-Moghaddadam (2007) contends that "women and the institutions set to protect and further their rights know that they are fair game if they cross the line and challenge conservative elements - knowledge that keeps them in a state of paralysis."

\section{Conclusion}

The lacunae between the rhetoric and realities of women's participation illuminate clear failures of the WPS strategy in recognizing multiple identities and subtle expressions of agency. Sustainable peace is an intersubjective phenomenon. The APRP has an inadequate focus on how peace is shaped by discourses and practices. It mistakenly assumes that its overall purpose is so apparent that examination or a genuinely broad dialog is not required. Lack of clear mechanisms for or recognition of dialog, as in the neglect of the Hizb-iIslami women's initiative, militates against a new consensus.

A central way in which feminism and crisis thinking may intertwine is when feminist ideas are co-opted to legitimize crisis interventions. International actors in the APRP, particularly women, believed they were working to improve the situation of all Afghan women. They were unaware or unconcerned about the suppression of those who did not share their vision of peace.

International actors, meanwhile, certainly did not anticipate that their participation in the APRP would bolster conservative positions on Sharia law and undermine the quest for women's rights, but their goal of a rapid exit stifled other aims. They employed the ruse of "cultural sensitivity" to conceal their interests. Clearly, feminist ideas serve diverse, often unintended purposes.

The goal of the APRP is to create the conditions for an inclusive peace by enfranchising the Taliban and other marginalized groups. Gender mainstreaming is intended to promote and enhance women's participation in all aspects of conflict prevention, management and resolution. However, a uni-dimensional understanding of gender that brackets out those women who have not internalized international norms fails to build the capacities of all 
women to engage in the peace process. This dichotomization of the universal and the local has proven highly counterproductive.

Heyzer warns that "we must guard against regarding gender equality and women's empowerment as a set of technical tools and concepts de-linked from practices, power and politics" (2005, p. 11). Overcoming dualities implies wider empowerment. If empowered communities are the site of transformative agency, the most expansive possible understanding of gender must be deployed. Ethics of care stand in sharp contrast to the artificiality of the application of universal standards.

Gilligan regards this uniform application as "morally problematic, since it breeds moral blindness of indifference" (2008, p. 471). Through the lens of the ethics of care, individuals have varying degrees of dependence and interdependence on one another. This differs from deontological and consequentialist perspectives, which tend to view them as having independent interests and interactions.

The gender dualism of the WPS agenda places men and women in contradiction with each other. The Taliban portray themselves as the protectors of Afghan culture and the purity of its women. This delineates an opposition: identifying with the West means rejecting Afghan heritage; while rejecting the West means clinging to tradition and accepting subordination. As Weeda Mehran, a women's rights activist, put it, "the solution is to pursue peace in ways that overcome the divide" (Interview, 2015).

\section{References}

Abu-Lughod, L. (2002). Do Muslim women really need saving?

Anthropological reflections on cultural relativism and its others.

American Anthropologist 104(3), 783-90. Available:

http://org.uib.no/smi/seminars/Pensum/Abu-Lughod.pdf

Afghanistan Online. The constitution of Afghanistan. Available:

http://www.afghan-web.com/politics/current_constitution.html

APRP. (2010). The Afghanistan Peace and Reintegration Program (APRP)

Executive Summary. Available:

https://ronna.apan.org/FRIC/APRP\%20Policy\%20Documents\%20Structu res $\% 20$ and $\% 20$ SOPs/APRP $\% 20$ Executive $\% 20$ Summary $\% 20-\% 20$ Final \%2012\%20July.pdf 
Amnesty International. (2015). Their lives on the line: Women human rights defenders under attack in Afghanistan. Available:

http://www.wluml.org/sites/wluml.org/files/ASA1112792015ENGLISH. pdf

Azarabaijani-Moghaddam, S. (2007). On living with negative peace and a half-built state: Gender and human rights. International Peacekeeping 14(1), 127-42.

Breines, I., Connell, R., \& Eide, I. (Eds.). (2000). Male roles, masculinities and violence: A culture of peace perspective. UNESCO. Available: http://unesdoc.unesco.org/images/0012/001206/120683E.pdf

Charlesworth, H., \& Chinkin, C. (2002). The boundaries of international law: A feminist analysis. Manchester: Manchester University Press. Elshatain, J. B. (1987). Women and war. Chicago: University of Chicago Press

Gilligan, C. (2008). Moral orientation and moral development. In A. Bailey \& C. J. Cuomo, The feminist philosophy reader. Boston: McGraw-Hill. Haress, G. (2014). Did politics compromise Afghanistan's constitution? Foreign Policy, October 23. Available: http://foreignpolicy.com/2014/10/23/did-politics-compromiseafghanistans-constitution/

Harris, A., \& King, Y. (Eds). (1989) Rocking the ship of state: Toward a feminist peace politics. Boulder, CO: Westview Press.

Harvey, D. C. (2016). Social policy as secondary violences in the aftermath of a disaster. Humanity and Society, February 23, 2016. Available: http://has.sagepub.com/content/early/2016/02/22/0160597616632803.abs tract

Heyzer, N. (2005). Making the links: women's rights and empowerment are key to achieving the Millennium Development Goals. In C. Sweetman (Ed.), Gender and the Millennium Development Goals. Oxford: Oxfam. Human Rights Watch. (2015). Afghanistan: Accept Full Role for Women in Talks. September 27. Available:

https://www.hrw.org/news/2015/09/27/afghanistan-accept-full-rolewomen-talks

Ministry of Foreign Affairs. (2015). Afghanistan's National Action Plan on UNSCR 1325 - Women, peace and security. Available: 
https://unama.unmissions.org/sites/default/files/wpsafghanistan national action plan 1325 0.pdf

Nemat, O. A. (2011). Afghan women at the crossroads: Agents of peace - or its victims? Available: https://tcf.org/assets/downloads/tcfafghanwomen_\%281\%29.pdf

Nordland, R. (2010). In bold display, Taliban order stoning deaths. The New York Times, August 16. Available: http://www.nytimes.com/2010/08/17/world/asia/17stoning.html? r $=2$

Oxfam. (2014). Behind closed doors: The risk of denying women a voice in determining Afghanistan's future. November. Available: https://www.oxfam.org/sites/www.oxfam.org/files/file_attachments/bp20 0-behind-doors-afghan-women-rights-241114-en.pdf

Quie, M. (2012). Peace-building and democracy promotion in Afghanistan: the Afghanistan Peace and Reintegration Program and reconciliation with the Taliban. Democratization 19(3), 553-74. Available: http://www.tandfonline.com/doi/abs/10.1080/13510347.2012.674362 Rose, N. (1999). Powers of freedom: Reframing political thought. Cambridge: Cambridge University Press.

Schwalbe, M. (1992). Male supremacy and the narrowing of the moral self. Berkeley Journal of Sociology 37, 29-54.

UN Partnership for Peace. Afghanistan's new beginnings program. Available: https://www.yumpu.com/en/document/view/42065012/afghanistans-newbeginnings-programme-cmi

United Nations Peacekeeping. Women, peace and security. Available: http://www.un.org/en/peacekeeping/issues/women/wps.shtml Wordsworth, A. (2007). A matter of interests: gender and the politics of presence in Afghanistan's Wolsei Jirga. Kabul: AREU. 
1207 Quie - Women and the Peace Process in Afghanistan

Marissa Quie Research Associate in the Department of Sociology, Faculty of Human, Social and Political Science, at University of Cambridge.

Contact address: Department of Sociology, Free School Lane, Cambridge CB2 3RQ, United Kingdom.

E-mail address: Mq10000@cam.ac.uk 